\title{
INTERELASI ORANGTUA, GURU DAN ANAK DALAM MEMBENTUK KARAKTER SISWA MADRASAH IBTIDAIYAH PLUS DARUL FALAH JOMBANG
}

\author{
Ida Fitri Shobihah \\ STAI Daruttaqwa Gresik \\ idafitrishobihah@staidagresik.ac.id \\ Putri Ziana Walidah \\ MI Plus Darul Falah Jombang \\ pziana19@gmail.com
}

\begin{abstract}
This research discusses the obstruction of activites in the world of early childhood education due to the covid 19 pandemic. The study aims to determine the extent of the Islamic kindergarten education institution Najmah Rugayah Darus, and it is associated with the tradition of the prophet Muhammad about the obligation to study. Data collection was carried out by means of research observation, interviewing school principals, teachers and seeing data on the number of students in school notebooks (documents) of the Islamic kindergarten education institution Najmah Rugayah Darus, the results of the research and interviews are described,and analyzed. The Islamic kindergarten education institution Najmah Rugayah Darus changes the teaching and learning proces, learning model even although due to covid 19the number of students has decreased. Hopefully the policies taken by the Islamic kindergarten education institution Najmah Rugayah Darus can be emulated by other early childhood education institutions.
\end{abstract}

Keywords:.

\begin{abstract}
Abstrak: Siswa adalah masa depan bangsa. Membentuk karakter siswa merupakan tanggung jawab guru dan orang tua. upaya membentuk karakter anak melalui pendidikan sudah dilakukan sejak zaman kolonial. Berbagai penelitian juga dilakukan untuk mengefektifkan proses pembentukan karakter tersebut. Tetapi, hambatan-hambatan yang berasal dari peran guru dan orang tua itu sendiri masih menjadi problematika yang urgent. Permasalahan sosial pada anak usia sekolah dasar yang tak kunjung selesai, tawuran dan perilaku seks yang tidak patut dilakukan oleh anak telah dilakukan. Maka dari itu, menemukan formula yang tepat dalam pembentukan karakter siswa menjadi semakin penting. Menemukan pola interelasi orang tua, guru dan anak itu sendiri dalam proses pembentukan karakter dapat menjadi jawaban atas hambatan-hambatan dalam proses tersebut. Sehingga penelitian ini dilakukan menggunakan metode kualitatif untuk menjawab pertanyaan penelitian: 1) bagiamana pola interelasi orang tua, guru dan anak dalam membentuk karakter siswa? 2) apa saja faktor yang mempengaruhi pola interelasi orang tua, guru dan anak dalam membentuk karakter siswa? Hasil menunjukkan bahwa terdapat dua pola interelasi yaitu melalui bertatap muka secara langsung dan melalui komunikasi tidak langsung. Faktor yang mempengaruhi yaitu integritas guru dan respons orang tua
\end{abstract}

Kata Kunci: : interelasi, pembentukan karakter siswa, guru, orang tua 


\section{Pendahuluan}

Madrasah Ibtidaiyah (MI) merupakan pendidikan formal jenjang pertama. Dasar-dasar pembelajaran diberikan pada masa tersebut, sehingga pembentukan karakter harus ditekankan dalam proses pembelajaran jenjang tersebut. Pada usia sekolah dasar, anak sedang mempelajari berbagai pengetahuan dasar untuk penyesuaian diri pada kehidupan dewasa nanti. ${ }^{1}$ Ketika anak mempelajari sesuatu dan mengembangkan menjadi perilakunya mkaan cenderung akan menetap dan menjadi bagian dari karakternya hingga saat dewasa. Maka dari itu, membentuk kebiasaan yang baik sejak usia sekolah dasar sangat tepat guna membentuk karakter siswa yang baik.

Karakter yang dikonsepkan oleh kementrian pendidikan Indonesia tertuang dalam bentuk nilai-nilai yang bersumber dari agama, pancasila, budaya, dan tujuan pendidikan nasional. Dari empat sumber utama tersebut kemudian kementrian pendidikan mengeluarkan kebijakan 18 nilai pendidikan karakter yang harus diimplentsikan dan dikembangkan di sekolah. Adapun 18 nilai pendidikan karakter itu adalah nilai religius, jujur, toleransi, disiplin, kerja keras, kreatif, mandiri, demokratis, rasa ingin tahu, semangat kebangsaan, cinta tanah air, menghargai prestasi, bersahabat/komunikatif, cinta damai, gemar membaca, peduli lingkungan, peduli sosial, dan tanggung jawab. ${ }^{2}$

Pendidikan karakter di sekolah terkait erat dengan manajemen model sekolah. Setiap sekolah harus mempunyai sistem pembelajaran yang akan dikembangkan. Melalui manajemen sekolah, setiap lembaga pendidikan akan menentukan sistem pembelajaran yang cocok dan sesuai dengan dengan visi dan misinya. Salah satu sistem pembelajaran dan model sekolah yang bisa mendukung implementasi pendidikan karakter adalah sistem full day school. Salah satu sekolah yang menggunakan sistem full day school adalah MI Plus Darul Falah Mojoagung Jombang.

pelaksanaan pendidikan karakter pada hakekatnya pasti sudah terkandung dalam setiap praktek pendidikan. Pendidikan karakter di Indonesia dimulai sejak zaman kolonial yang ditandai dengan dibukanya sekolah formal untuk pribumi. ${ }^{3}$ Hingga saat ini pun berbagai program dilakukan guna memaksimalkan pendidikan karakter pada siswa-siswi Indonesia. Akan tetapi, permasalah dalam pendidikan terus bermunculan seperti pada 24 Mei 2018 diberitakan bangkapos.com seorang siswa SD di Tulungagung menghamili pacarnya. ${ }^{4}$ Berita lain pada tanggal 20 April 2018 menyampaikan bahwa gara-gara lewat tanpa permisi, anakanak SD bersenjata nekat tawuran. 15 anak dengan masing-masing membawa senjata tajam menghampiri sekolah dasar lain untuk menyerangnya. ${ }^{5}$ Dan beberapa peristiwa lain yang terjadi, dimana pada saat ini masih membutuhkan upaya yang maksimal dalam membentuk karakter siswa terutama pada siswa sekolah dasar.

Terdapat beberapa faktor yang mempengaruhi keberhasilan dalam upaya membentuk karakter siswa, yakni peran guru dan peran orang tua. guru sangat berpengaruh karena guru adalah mentor utama dalam proses pembelajaran dan menjadi model bagi siswa. ${ }^{6}$ Sehingga

\footnotetext{
${ }^{1}$ Elizaeth B. Hurlock, psikologi perkembangan, (Jakarta: Erlangga, 1994), h, 146.

${ }^{2}$ Kementrian pendidikan nasioal. Pusat kurikulum kemetrian pendidikan nasional, (Jakarta: 2010).

${ }^{3}$ Siti Patimah, Formalisme Pendidikan Karakter di Indonesia, Jurnal JJP Vol.XVII, no.1, (2012), h. 118.

${ }^{4}$ Surya, Bocah SD Hamili Siswi SMP di Tulungagung Kenalan di Pantai hingga Pacaran Kebablasan,

(bangkapos.com, 24 Mei 2018), http://bangka.tribunnews.com/amp/2018/05/04.

${ }^{5}$ Muhammad Iqbal Maulud, Gara-gara lewat tanpa permisi, anak-anak SD bersenjata tajam ini nekat tawuran, (pikiranrakyat.com, 20 April 2018), http://pikiran-rakyat.com/jawa-barat/2018/04/20.

${ }^{6}$ Nur Syamsi, Membentuk karakter peserta didik melalui proses pembelajaran oleh guru kelas di MI/SD. Jurnal

Tarbiyah Al-Awlad, Vol.4, edisi 1, (2015).
} 
guru memiliki peran penting dalam membangun karakter siswa yang baik. ${ }^{7}$ Tidak kalah pentingnya, orang tua yang memiliki waktu lebih banyak dengan anak juga menjadi penentu karakter anak tersebut. ${ }^{8}$

Meskipun setiap faktor telah dikaji dan diupayakan dengan maksimal, namun terdapat berbagai hambatan yang ada dalam proses pembentukan karakter, seperti kurangnya pemahaman pendidik mengenai karakter siswa, kurangnya sarana penunjang dalam penyelenggaraan kegiatan pembelajaran, dan kurangnya partisipasi aktif orang tua dalam pembentukan karakter siswa. ${ }^{9}$ Sehingga penelitian ini berupaya menemukan keterkaitan antar faktor tersebut dalam memaksimalkan pembentukan karakter siswa guna mengatasi hambatan-hambatan yang muncul dalam proses tersebut.

Berdasarkan latar belakang yang telah dijelaskan di atas, penelitian ini memiliki rumusan masalah sebagai berikut: Bagaimana pola interelasi orang tua, guru dan anak dalam membentuk karakter siswa MI Plus Darul Falah dan apa saja faktor yang mempengaruhi pola interelasi orang tua, guru dan anak dalam membentuk karakter siswa MI Plus Darul Falah. Dengan tujuan untuk: Mengetahui pola interelasi orang tua, guru, dan anak dalam membentuk karakter siswa MI Plus Darul Falah dan mengetahui faktor yang mempengaruhi pola interelasi orang tua, guru dan anak dalam membentuk karakter siswa MI Plus Darul Falah.

Perbedaan dengan penelitian sebelumnya adalah penelitian ini berusaha mengkaji pembentukan karakter siswa dengan dimensi lebih luas. Berbeda dengan penelitian sebelumnya yang hanya mengkaitkan dengan satu faktor, orang tua atau guru saja. Penelitian ini mencoba melihat keterkaitan atau interelasi orang tua, guru dan anak dalam memaksimalkan proses pembentukan karakter. Selain itu, penelitian ini mencoba menemukan pola-pola interelasi tersebut sehingga dapat membentuk karakter siswa dengan dengan berbagai latar belakang yang dimiliki

\section{Membentuk Karakter (Character Building)}

Membentuk karakter adalah tujuan pendidikan di Indonesia yang disebut dengan pendidikan karakter. Pendidikan karakter merupakan pengajaran yang dirancang untuk membentuk karakter siswa sesuai dengan karakter yang diharapkan. Pendidikan karakter merupakan proses pembentukan karakter siswa dimulai pada siswa bersekolah formal tingkat dasar bahkan mulai pada masa kelompok bermain, hingga siwa di jenjang atas.

Pendidikan karakter yang dirumuskan oleh kemdiknas terdiri dari sembilan pilar. Kesembilan pilar itu dirancang untuk diimplementasikan pada semua jenjang pendidikan. Sembilan pilar pendidikan karakter tersebut adalah: (1) cinta Tuhan dan segenap ciptaanNya; (2) kemandirian dan tanggung jawab; (3) kejujuran/amanah dan diplomatis; (4) hormat dan santun; (5) dermawan, suka tolong-menolong dan gotong royong/kerjasama; (6) percaya diri dan kerja keras; (7) kepemimpinan dan keadilan; (8) baik dan rendah hari; (9) toleransi, kedamaian, dan kesatuan. ${ }^{10}$

\footnotetext{
${ }^{7}$ Machful Idra Kurniawan, Mendidik untuk membentuk karakter siswa sekolah dasar: studi analisis tugas guru dalam mendidik siswa berkarakter pribadi yang baik. Journal Pedagogia, vol.4, No.2, (Agustus, 2015).

${ }^{8}$ Ali Muhsin, Upaya Orang Tua dalam Membentuk Karakter Anak di Dusun Sumbersuko Desa Plososari Kecamatan Grati Kabupaten Pasuruan. Dinamika, Vol.2, No.2, (Desember, 2017).

${ }_{9}$ Danu Eko Agustinova, Hambatan Pendidikan Karakter di Sekolah Islam Terpadu Studi Kasus SDIT Al-Hasna Klaten, SOCLA Jurnal Ilmu-Ilmu Sosial, vol.12, no.1, (2015), h.12-18.

${ }^{10}$ Siti Patimah, Formalisme Pendidikan Karakter di Indonesia. Jurnal JJP Vol.XVII, no.1, (2012).
} 
Karakter itu bukanlah bersifar given. Oleh karena itu pembentukan dan perubahan karakter sangat mungkin untuk dilakukan melalui pendidikan. Meskipun memang butuh waktu dan melalui proses yang panjang. Pendidikan karakter dpat dibangun melalui tiga pondasi yakni pendidikan, agama dan budaya bangsa. Apabila ketiga pondasi dapat diajarkan dengan baik maka dapat membentuk siswa yang berakhlakul karimah (akhlak yang baik). Mengajarkan bukan berarti sekedar menjadikan pendidikan karakter sebagai bagian dari mata pelajaran, tetapi mengajarkan tindakan-tindakan nyata yang dapat membentuk karakter siswa. $^{11}$

\section{Interelasi Orang Tua, Guru dan Anak dalam Membentuk Karakter Siswa}

Keberhasilan dalam membentuk karakter siswa ditentukan oleh peran guru dan peran orang tua. pertama, peran guru. Guru sangat berpengaruh karena guru adalah pendidik dalam proses pembelajaran, menjadi model bagi siswa dan mentor dalam melakukan berbagai kegiatan. ${ }^{12}$ Sehingga guru memiliki peran penting dalam membangun karakter siswa yang baik. ${ }^{13}$ Guru yang dapat membentuk karakter siswa adalah guru yang mampu memahami karakter pribadi siswa. Dengan mampu mengenali, menghayati dan mengarahkan siswa, guru mampu melakukan tujuan tersebut. ${ }^{14}$ Ketika guru tidak mampu memahami karakter siswa maka, proses pembentukan karakter siswa akan terhambat, sehingga pendidikan karakter tidak membuahkan hasil maksimal. ${ }^{15}$

Kedua, peran orang tua. Orang tua adala orang yang memiliki waktu lebih banyak bersama anak. ${ }^{16}$ Orang tua merupakan pendidikan pertama yang diterima oleh anak. Meskipun saat usia sekolah, taggung jawab orang tua dibagi dengan guru, orang tua juga tetap berperan penting dalam membentuk karakter anak. Orang tua melakukan berbagai hal untuk mendidik anak seperti memberikan contoh, nasehat, reward dan punishment. Tetapi, sebagai orang tua juga memiliki hambatan yakni kesibukan orang tua terutama keduanya adalah pekerja. Disisi lain, perkembangan teknologi yang pesat membuat anak membutuhkan pendampingan ketat. Ketika orang tua tidak mampu memberikan pendampingan, maka karakter anak tidak dapat terbentuk dengan baik. ${ }^{17}$

Orang tua dan guru yang sama pentingnya dalam membentuk karakter anak, akan lebih menunjukkan hasil maksimal ketika terdapat kolaborasi diantara keduanya. Terdapat berbagai bentuk kerjasama antara orang tua dan guru seperti, menjalin komunikasi timbal balik untuk membangun persepsi yang positif, ${ }^{18}$ mendirikan perkumpulan, melakukan

\footnotetext{
${ }^{11}$ Ibid.

12 Nur Syamsi, Membentuk karakter peserta didik melalui proses pembelajaran oleh guru kelas di MI/SD. Jurnal Tarbiyah Al-Awlad, Vol.4, edisi 1, (2015).

${ }^{13}$ Machful Idra Kurniawan, Mendidik untuk membentuk karakter siswa sekolah dasar: studi analisis tugas guru dalam mendidik siswa berkarakter pribadi yang baik. Journal Pedagogia, vol.4, No.2, (Agustus, 2015).

14 Arifin, Membangun karakter siswa sebagai kontribusi terhadap karakter bangsa melalui pendekatan psikologis. JESA Jurnal Edukasi Sebelas April, Vol.1, No.1, (Februari, 2017).

${ }^{15}$ Danu Eko Agustinova, Hambatan Pendidikan Karakter di Sekolah Islam Terpadu Studi Kasus SDIT Al-Hasna Klaten, SOCLA Jurnal Ilmu-Ilmu Sosial, vol.12, no.1, (2015), h.12-18.

16 Ali Muhsin, Upaya Orang Tua dalam Membentuk Karakter Anak di Dusun Sumbersuko Desa Plososari

Kecamatan Grati Kabupaten Pasuruan. Dinamika, Vol.2, No.2, (Desember, 2017).

${ }^{17}$ Ibid.

18 Ariadi Nugraha dan Fuad Aminur Rahman, Strategi Kolaborasi Orang tua dengan Konselor dalam Mengembangkan Sukses Studi Siswa. Jurnal Konseling GUSJIGANG, vol.3, no.1, (2017).
} 
sosialisasi pendidikan karakter, melibatkan orang tua dalam perencanaan program, membuat kesepakatan dan menerima kritik dan saran. ${ }^{19}$

Selain itu, faktor lain yang tidak kalah penting adalah anak itu sendiri. Setiap anak memiliki potensi masing-masing dan pengalaman yang berbeda dan menjadi bagian dari diri anak tersebut. Bagaimana keadaan anak tersebut menentuk keberhasilan proses pembentukan karakternya. Anak yang memiliki karakter kuat dan tidak mudah dipengaruhi oleh orang lain akan mudah memegang teguh nilai-nilai yang telah diajarkan. Anak yang demikian adalah anak yang mampu meregulasi moralnya. Begitu juga sebaliknya. Sehingga penting untuk mengetahui karakter dari anak tersebut. ${ }^{20}$

Kolaborasi antara orang tua dan guru tentunya dapat dilakukan dalam berbagai bentuk sikap dan perilaku. Melalui kerjasama yang terjali diantara keduanya, akan membentuk pola interelasi antara orang tua, guru dan anak itu sendiri. Upaya yang dilakukan sama tetapi proses relasinya dapat berbeda sesuai dengan masing-masing latar belakang siswa dan orang tua tersebut. Inti dari proses interelasi dari ketiga unsur tersebut adalah bahwa satu sama lain saling terkait dan berpengaruh, sehingga dalam mengupayakan pembentukan karakter harus memiliki interelasi yang tepat. Pola interelasi orang tua, guru dan anak dapat digambarkan sebagaimana gambar berikut:

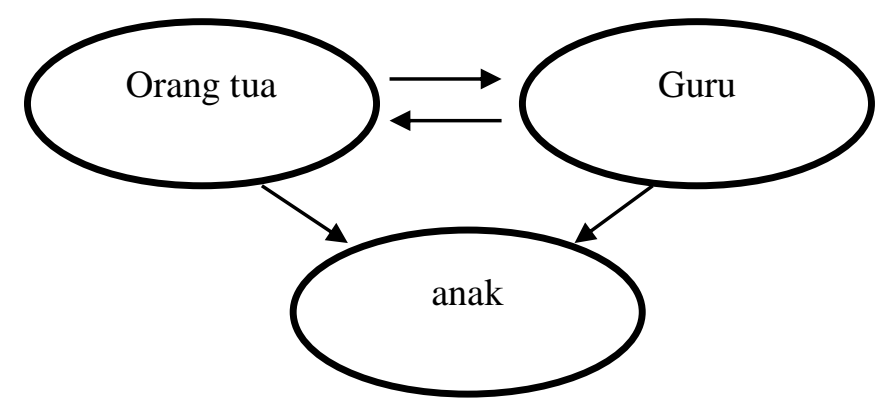

Gambar 1. Pola interelasi orang tua, guru dan anak dalam membentuk karakter siswa

\section{Metode Penelitian}

Metode penelitian dalam penelitian ini adalah metode penelitian kualitatif dengan pendekatan indigenous psychology. Sedangkan Teknik pengumpulan data yang digunakan dalam penelitian ini adalah wawancara dan observasi. Creswell menjelaskan bahwa penelitian yang bertujuan untuk mengeksplorasi suatu fakta menjadi lebih tepat dengan metode penelitian kualitatif. Sehingga dapat menemukan makna dari fakta tersebut. ${ }^{21}$

Penelitian dilakukan di MI Plus Darul Falah Mojoagung Jombang. Sekolah tersebut merupakan salah satu lembaga pendidikan dasar yang menyelenggarakan program bidang pengembangan diri seperti pelaksanaan bimbingan konseling. Program yang dilakasanakan meliputi kegiatan parenting sekali setiap semester, bimbingan konseling individual dan kelompok. Wawancara dilakukan kepada 6 orang tua dan 3 guru. Observasi dilakukan kepada anak serta aktivitas pembelajaran di sekolah.

\footnotetext{
${ }_{19}$ Aprilia Krisnawanti, Kerjasama Guru dengan Orang tua dalam Membentuk Karakter Disiplin Siswa Kelas V SD Negeri Gembongan. Jurnal Pendidikan Guru Sekolah Dasar, Edisi 18, (2016).

${ }^{20}$ Sri Lestari, Pembentukan karakter pada anak: Model mekanisme sanksi diri dari albert Bandura sebagai regulasi perilaku moral, Buletin Psikologi, vol. 17, no. 1, (2009), h. 55.

${ }^{21}$ John W. Creswell, Research Design Pendekatan Kualitatif, Kuantitatif dan Mixed, (Yogyakarta: Pustaka Pelajar, 2014), h. 270-271.
} 
Data yang diperoleh dianalisis menggunakan teknik analisis deskriptif. Yakni data dideskripsikan dengan alur yang saling dikaitkan antara data satu dengan data lain menjadi dinamika psikologis yang utuh. Sedangkan keabsahan data dalam penelitian ini dilakukan melalui triangulasi data yang diperoleh dari berbagai teknik pengambilan data tersebut.

\section{Hasil dan Pembahasan}

Hasil menunjukkan bahwa anak didik tingkat sekolah dasar dalam proses pembentukan kemandirian dan tangggung jawab pada dirinya. Selama proses tersebut peran orang dewasa disekitarnya menjadi penting. Menyadari hal tersebut pada lembaga pendidikan MI Plus Darul Falah Jombang membuat program yang melibatkan orang tua guru dan anak dalam proses pendampingan.

Komunikasi antara orang tua dengan guru dalam lingkungan madrasah dapat terjadi melalui mediasi program madrasah. Orang tua memiliki dua tipe dalam berkomunikasi dengan pihak madrasah tempat anaknya bersekolah. Yaitu, tipe pasif dan aktif. Tipe pasif adalah model komunikasi antara orang tua dengan guru terjadi apabila pihak sekolah atau guru yang mengawali komunikasi. Sedangkan tipe aktif adalah model komunikasi orang tua dengan guru yang mana orang tua tidak enggan untuk memulai dahulu komunikasi dengan pihak sekolah terkait perkembangan anak di sekolah. Akan tetapi, model komunikasi yang dominan adalah cenderung pasif.

Program madrasah bidang pengembangan diri atau bimbingan konseling menjadi jembatan antara guru dan orang tua dalam berkomunikasi mengenai perkembangan anak. Melalui pertemuan yang diagendakan oleh sekolah baik secara individual, kelompok maupun klasikal. Orang tua awalnya enggan menjadi terbuka kepada pihak madrasah. Saat mendapat surat undangan dari sekolah terkait perkembangan anak, orang tua menunjukkan kehadiran tepat waktu sebagaimana yang tercantum dalam undangan. Berawal dari penyampaian guru terkait perkembangan anak yang terdiri dari kelebihan dan kekurangan dari anak. Orang tua merasa senang karena hal tersebut menjadi wujud dari kepedulian sekolah kepada anak dan merasa beruntung telah menyekolahkan anaknya di madarasah tersebut. Dengan demikian orang tua menjadi terbuka dengan guru dan mengungkapkan segala hal terkait dengan sikap dan perilaku anak ketika di rumah.

Informasi yang diterima guru dari orang tua membantu guru lebih mudah dalam menemukan solusi atas kendala yang dihadapi dalam mendampingi anak. Informasi yang diterima orang tua dari guru membuat orang tua menjadi lebih semangat dalam mendampingi belajar dan beraktivitas di rumah karena mengetahui sejauhmana kemampuan yang dimiliki oleh anaknya. Hal ini menunjukkan adanya manfaat komunikasi yang terjalin antara guru dan orang tua yang saling menguntungkan. Komunikasi yang terjalin secara efektif dapat memberikan dampak positif dalam saling ketergantungan antar pelaku dalam komunikasi tersebut. Komunikasi efektif sangat berperan dalam menentukan kualitas proses pembelajaran. ${ }^{22} \mathrm{Hal}$ yang berbeda dalam penelitian ini adalah komunikasi efektif tidak hanya harus dicapai antara guru dengan murid tetapi juga guru dengan orang tua.

Melalui komunikasi efektif yang terjalin antara guru, orang tua dan anak juga dapat memberikan ruang kepada anak untuk menunjukkan potensi yang dimiliki sehingga

\footnotetext{
22 Tutut Handayani, Membangun Komunikasi Efektif Untuk Meningkatkan Kualitas dalam Proses Belajar Mengajar, Ta'dib, Vol.XIV, No.2, 2011, h,273-303.
} 
kreativitas anak dapat diekspresikan dengan maksimal. ${ }^{23}$ Komunikasi terjadi antara tiga komponen tersebut terjadi melalui beberapa model. Pertama, melalui program madrasah yang menyelenggarakan program bimbingan konseling sehingga terdapat upaya yang dilakukan pihak madrasah untuk melakukan komunikasi secara langsung dengan ketiga komponen tersebut. Kedua, komunikasi tidak langsung yakni terjadi melalui guru dengan orang tua, anak dengan orang tua, dan guru dengan anak yang mana dalam masing-masing bagian tersebut dalam satu topic yakni tentang perkembangan anak.

Terdapat beberapa hal yang dapat membantu tercapainya komunikasi efektif dalam interelasi guru, orang tua dan anak. Pertama, integritas diri guru. Dalam komunikasi tentang perkembangan anak yang terjadi antara guru dengan orang tua, integritas guru menjadi hal penting, guru merupakan sosok yang dipercaya dan dihormati.

Kedua, respons orang tua. Guru menyampaikan setiap hasil pendampingan kepada anak baik dalam hal positif maupun negatif. Respon orang menjadi bagian penting dalam menentukan tidak lanjut pendampingan anak tersebut. Upaya komunikasi dengan orang tua dilakukan secara langsung dan tidak langsung. Secara langsung dilakukan melalui undangan resmi secara cetak dengan tandatangan mengetahui kepala madrasah. Secara tidak langsung, komunikasi dilakukan dengan media whatsapp. Cara kedua dilakukan hanya dalam situasi mendesak. Baik dengan cara pertama maupun kedua sangat membutuhkan respon orang tua.

Respon yang dibutuhkan dalam upaya memaksimalkan pendampingan anak adalah respon yang aktif. Seperti ketika orang tua diajak berkoordinasi dengan guru, orang tua memberikan tanggapan dan mau melakukan kerjasama dengan guru. Respon yang bersifat pasif juga tidak memberikan dampak positif karena membuat guru ragu-ragu dalam mengambil tindak. Sehingga respon yang pasif sama halnya dengan tidak memberikan respon.

\section{Kesimpulan}

Pola interelasi antara guru, orang tua, dan anak dalam membentuk karakter siswa terbentuk menjadi dua model. Yakni bertatap muka secara langsung dari ketiga komponen melalui program madrasah dan melalui komunikasi tidak langsung yang terbagi menjadi tiga bagian yaitu guru dengan orang tua, guru dengan anak, orang tua dengan anak. Selain itu, terdapat dua faktor yang mempengaruhi yaitu integritas guru dan respons orang tua.

\section{Daftar Pustaka}

Agustinova, Danu Eko. (2015). Hambatan Pendidikan Karakter di Sekolah Islam Terpadu Studi Kasus SDIT Al-Hasna Klaten. SOCIA Jurnal Ilmu-Ilmu Sosial, vol.12, no.1, 12-18.

Arifin. (2017). Membangun karakter siswa sebagai kontribusi terhadap karakter bangsa melalui pendekatan psikologis. JESA Jurnal Edukasi Sebelas April, Vol.1, No.1.

\footnotetext{
${ }^{23}$ Anis Pusitaningntyas, Pengaruh Komunikasi Orang tua dan Guru Terhadap Kreativitas Anak, proceeding of ICECRS, Vol.1, 2016, h.935-942.
} 
Creswell, John W. (2014). Research Design Pendekatan Kualitatif, Kuantitatif dan Mixed. Yogyakarta: Pustaka Pelajar.

Handayani, T. (2011). Membangun Komunikasi Efektif Untuk Meningkatkan Kualitas dalam Proses Belajar Mengajar. Ta'dib, Vol.XIV, No.2, h,273-303.

Hurlock, Elizaeth B. (1994). Psikologi Perkembangan. Jakarta: Erlangga.

Kementrian Pendidikan Nasioal. (2010). Pusat kurikulum kemetrian pendidikan nasional, Jakarta.

Krisnawanti, Aprilia. (2016). Kerjasama Guru dengan Orang tua dalam Membentuk Karakter Disiplin Siswa Kelas V SD Negeri Gembongan. Jurnal Pendidikan Guru Sekolah Dasar, Edisi 18 tahun ke5.

Kurniawan, Machful Idra. (2015). Mendidik untuk membentuk karakter siswa sekolah dasar: studi analisis tugas guru dalam mendidik siswa berkarakter pribadi yang baik. Journal Pedagogia, vol.4, No.2.

Lestari, Sri. (2009). Pembentukan karakter pada anak: Model mekanisme sanksi diri dari albert Bandura sebagai regulasi perilaku moral, Buletin Psikologi, vol. 17, no. 1.

Muhsin, Ali. (2017). Upaya Orang Tua dalam Membentuk Karakter Anak di Dusun Sumbersuko Desa Plososari Kecamatan Grati Kabupaten Pasuruan. Dinamika, Vol.2, No.2.

Nugraha, Ariadi dan Fuad Aminur Rahman. (2017). Strategi Kolaborasi Orang tua dengan Konselor dalam Mengembangkan Sukses Studi Siswa. Jurnal Konseling GUSJIGANG, vol.3, no.1.

Patimah, Siti. (2012). Formalisme Pendidikan Karakter di Indonesia. Jurnal JJP Vol.XVII, no.1.

Pusitaningntyas, A. (2016). Pengaruh Komunikasi Orang tua dan Guru Terhadap Kreativitas Anak. proceeding of ICECRS, Vol.1, h.935-942.

Syamsi, Nur. (2015). Membentuk karakter peserta didik melalui proses pembelajaran oleh guru kelas di MI/SD. Jurnal Tarbiyah Al-Awlad, Vol.4, edisi 1. 